бульбашок 1-3мм.

\title{
Висновки.
}

Доведено, що використання даних дієтичних добавок у технології солодкої страви «Повидлянка» дозволяє покращити вихідний продукт та забезпечує економічність технологічних процесів виготовлення готової продукції.

Перспективи подальших досліджень. Подальшими дослідженнями передбачається вивчення хімічного складу нової страви.

Література:

1. Попов В. Г., Бутина Е. А., Герасименко Е. О. Разработка новых видов функциональных пищевых продуктов с заданными физиологически активными свойствами // Новые технологии. 2009. №4 С.25-32.

2. Гніцевич, В. А., Актуальні проблеми виробництва солодких страв 3 пінною структурою. Обладнання та технології харчових виробництв. Тематичний збірник наукових праць. Випуск 4 (2003): 182-185.

Токаэв Э.С., Мироедов Р.Ю., Некрасов Е.А., Хасанов А.А. Технология продуктов спортивного питания. - М.: МГУПБ, 2010. - 108 с.

3. Нечитайло I. Несподівані "панацеї" (біологічно активні харчові добавки)/ - Пульсар. - 2001 - №11 - с. 66.

4. Просеков А. Ю. Роль межфазных поверхностных явлений в производстве дисперсных продуктов с пенной структурой / А. Ю. Просеков // Хранение и переработка сельхозсырья. - 2001. - № 8. - С. 24-27.

5. Просеков А. Ю. Влияние различных технологических факторов на качество пенообразных пищевых масс / А. Ю. Просеков // Хранение и переработка сельхозсырья. - 2001. - № 10. - С. 15-17.

Стаття надіслана: 20.02.2017 p.

(C) Сазонова Д.Ю.

\author{
ЦИТ: иа117-041
}

DOI: 10.21893/2415-7538.2016-05-1-041

УДК 681.518.5

Бендерська О.В., Коваль М. О. АНАЛІЗ НІТРАТНОГО ЗАБРУДНЕННЯ ЗРАЗКІВ ПИТНОЇ ВОДИ М. КИСВА ТА КИЇВСЬКОЇ ОБЛАСТІ

Наиіональний університет харчових технологій, Київ, Володимирська 68, 01601

Benderska O., Koval M. ANALYSIS NITRATE POLLUTION SAMPLES OF DRINKING WATER KYIV AND KYIV REGION

National University of Food Technologies, Kyiv-33, Volodymyrska str.68, 01601,

Анотачія. Сьогодні в Україні проблема екологічної безпечності продуктів харчування та питної води є надзвичайно актуальною. Так, до організму людини 70 \% шкідливих речовин потрапляють з їжею, 30 \% - 
повітрям. Навіть за умови невисокої токсичності забруднюючих речовин тривале споживання продуктів та води, щзо їх містять, спричинює хронічну інтоксикацію $і$ розвиток патологічних змін в організмі людини. До таких сполук відносяться $i$ нітрати. Забруднення продуктів харчування $i$ води нітратами небезпечне для здоров'я. Токсичність нітратів є наслідком ланцюга реакиій нітрат- нітрит - N-нітрозосполуки, які є канцерогенними речовинами. Нітрити здатні окислювати гемоглобін до метгемоглобіну, який не може переносити кисень - розвивається хвороба метгемоглобінемія летальні випадки від якої у дітей до одного року реєструються все частіше. Нітрати знижують резистентність організму та сприяють зростанню загальної захворюваності, зокрема інфекиійними захворюваннями.

Ключові слова: водні ресурси, нітрати, нітрити, технологія, безпечність, харчова промисловість.

Abstract. Today in Ukraine the problem of environmental safety of food and drinking water is extremely important. Yes, the human body $70 \%$ of pollutants come from food, 30\% - water and air. Even with low emission of pollutants and long-term consumption of water containing them, causing chronic intoxication and the development of pathological changes in the human body. These compounds include and nitrates. Contamination of food and water with nitrates is dangerous to health. Nitrate toxicity is the result of a chain reaction of nitrite nitrate - N-nitroso compounds, which are carcinogenic substances. Nitrites are able to oxidize hemoglobin to methemoglobin, which can not carry oxygen - evolving methemohlobanemiya disease, deaths from which children under one year registered more often. Nitrates lower the body's resistance and promote the growth of overall morbidity, including infectious diseases.

Key words: water, nitrates, nitrites, technology, safety, food industry

Вступ

В наш час проблема видалення нітрат-іонів стає все більш важливою при підготовці питної води, що обумовлено високою токсичністю нітрат-іонів та їх поширенням у природних водах. У водні об'єкти нітрат-іони потрапляють 3 атмосферними опадами, 3 накопиченими твердими відходами, 3 побутовими стічними водами та стічними водами підприємств, а також у результаті використання мінеральних азотних добрив у сільському господарстві. У зоні надмірного застосування мінеральних добрив i пестицидів значно частіше зустрічаються гострі респіраторні захворювання, пневмонія, туберкульоз легенів, зростання числа захворювань печінки, серцево-судинної системи i виникнення ракових пухлин у шлунково-кишковому тракті [1].

\section{Огляд літератури.}

Природна вода, тобто вода підземних джерел і поверхневих водойм складна дисперсна система. Частина хімічних сполук у воді не розчиняється, утворюючи зважені речовини, суспензії або емульсії, інші розчиняються в різному ступені. Найбільшою мірою в воді розчиняються хлориди, сульфати i нітрати лужних і лужноземельних металів [1, 2].

При взаємодії нітратів 3 ароматичними i аліфатичними амінами в відкритих водоймах можуть утворюватися нітрозаміни і нітрозаміди, речовини, 
які можуть надходити в воду джерел централізованого водопостачання. Дані сполуки добре розчинні, володіють високою стабільністю в водному середовищі і є активними канцерогенами і мутагенами [3].

Допустима добова доза нітратів, за даними експертів ВOO3, становить 5 мг на 1 кг маси тіла, або 350 мг для людини 3 масою тіла 70 кг. За концентрації нітратів у воді на рівні гігієнічного нормативу (45 мг/л) протягом доби 33 л води в організм людини може надійти 135 мг нітратів. Гострі отруєння в дорослих спостерігалися за надходження 1..4 г нітратів. Доза 8 г нітратів може призвести до загибелі людини, а доза 13...14 г є абсолютно смертельною [4].

\section{Результати. Обговорення і аналіз.}

Метою даної роботи була оцінка якості питної води з бюветів та джерел децентралізованого водопостачання за вмістом нітратів та виявлення найбільш забруднених (небезпечних) місць для споживання питної води. Проблема забруднення водоносного горизонту нітрат-іонами є вкрай суттєвою для м. Києва та Київської області, в якій немає жодного району без перевищення цього показника у воді децентралізованого водопостачання [5, 6], чим i викликана актуальність нашого дослідження. проаналізувати загальний рівень

Відбір проб проводили відповідно до ДСТУ ISO 5667-1-2003 [7].

Було відібрано і проаналізовано 45 зразків питної води із бюветів м. Києва та родовищ Київської області. Вміст нітрат-іонів визначали потенціометричним методом 3 використанням нітратселективного електроду відповідно до ГОСТ 18826-73 [6].

Для отримання результатів використовували нітратомір IT-1201. Метод грунтується на принципі прямого визначення нітрат-іонів з використанням іонселективного електроду. Для цього відбирали проби по $25 \mathrm{~cm}^{3}$ досліджуваних зразків, доводили об'єм до $50 \mathrm{~cm}^{3}$ за допомогою $10 \%$ фонового розчину алюмокалієвих галунів та проводили визначення кількості нітрат-іонів.

Дослідження проводили в березні 2017 року, оскільки за деякими даними [8] саме у весняні місяці концентрація нітратів у воді сягає максимальних значень. Зокрема відібрано 10 зразків питної води із бюветів м. Києва та 30 зразків із родовищ Київської області. Діапазон значень вмісту нітратів коливається від 8,56 мг/л до 10,06 г/л.

Серед зразків, що відбиралися в м. Київ, представлено проби із бюветів Дніпровського, Подільського, Шевченківського, Голосіївського, Солом'янського, Печерського, Оболонського районів. Значення показників концентрації нітрат-іонів для бюветів м. Києва містяться в діапазоні 8,56 мг/л до 105,3 мг/л. Серед 11 проаналізованих зразків перевищення допустимого рівня нітратів вдвічі зареєстровано в 2 зразках (рис. 1): із бювету на вул. Дегтярівській Шевченківського району та бювету на вул. Каблукова Солом'янського району.

Аналіз зразків із родовищ та бюветів Київської області свідчить про високий рівень забруднення нітратами - серед 34 аналізованих проб 23 мали значне перевищення допустимого рівня концентрації нітрат-іонів. Відстежується тенденція високої забрудненості води в сільській місцевості. Діапазон значень коливається від 71,2 мг/л до 10,06 г/л. 


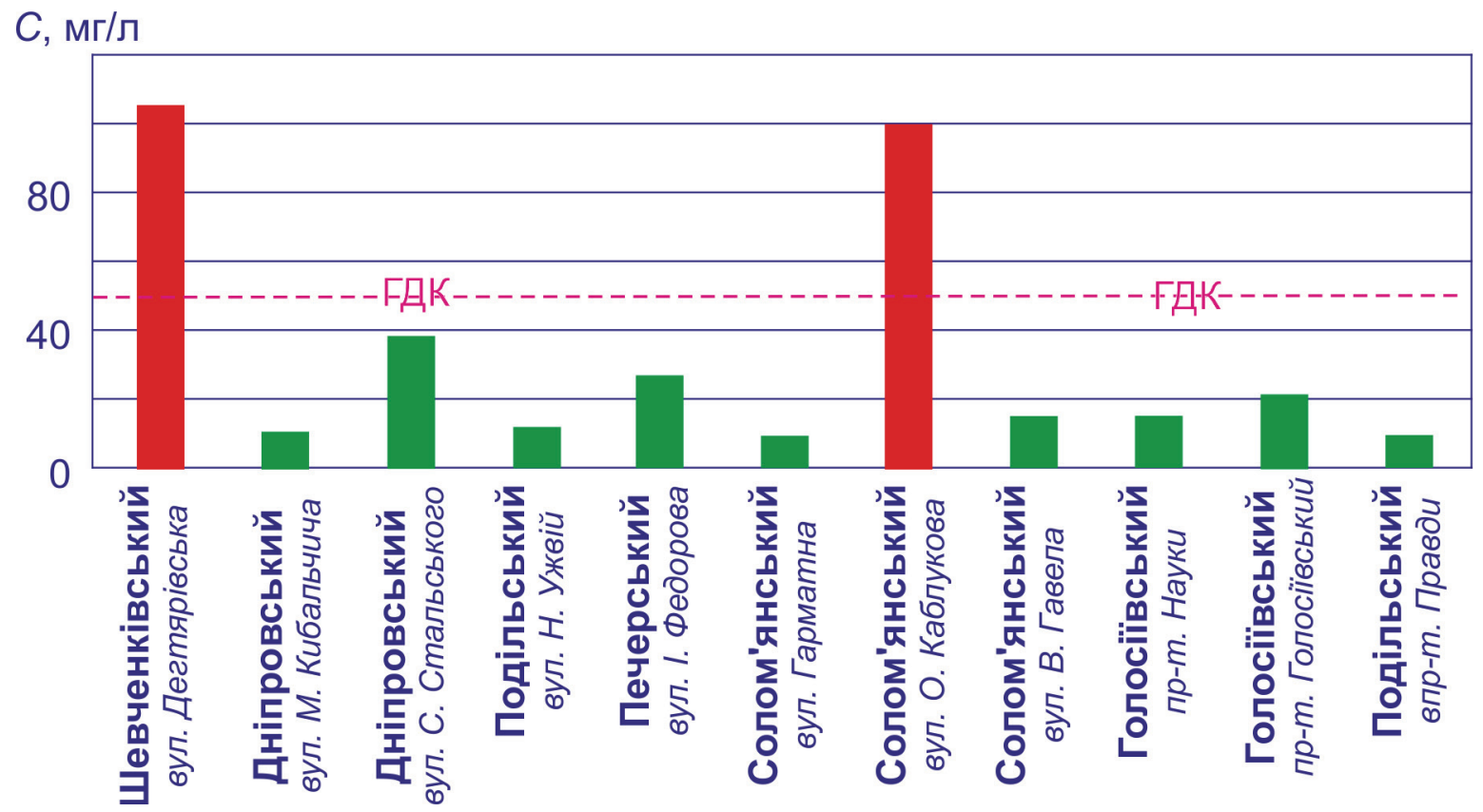

Рис. 1. Вміст нітратів у воді бюветів по районах м. Кисва

Критичний рівень нітратного забруднення зафіксовано у зразку із свердловини с. Гребінки, Васильківського району - ГДК перевищено у 200 разів.

Високі концентрації нітратів зафіксовано для зразків із м. Боярка КиєвоСвятошинського району - перевищення ГДК в 50 разів; м. Біла Церква - високі рівні нітратів у всіх п'яти досліджуваних зразках та с. Гоголів Броварського району - перевищено допустимі норми вмісту нітратів в майже 44 рази (табл. 1).

Решта зразків мали незначне перевищення рівня ГДК $[3,6]$.

Таблиця 1

Вміст нітратів у зразках води по районах Київської області

\begin{tabular}{|l|l|l|l|}
\hline $\begin{array}{c}\text { № } \\
3 / \Pi\end{array}$ & \multicolumn{1}{|c|}{ Місце забору проб } & $\begin{array}{c}\text { Кількість зразків, } \\
\text { (більше/менше) ГДК }\end{array}$ & $\begin{array}{c}\text { Концентрація } \\
\mathrm{NO}_{3}- \\
\min -\operatorname{max,~мг/л~}\end{array}$ \\
\hline 1 & Києво-Святошинський район & $9(4 / 5)$ & $10,53-2251$ \\
\hline 2 & Броварський район & $4(2 / 2)$ & $17,8-1961$ \\
\hline 3 & Обухівський район & $3(1 / 2)$ & $40,96-650$ \\
\hline 4 & Макарівський район & $8(6 / 2)$ & $13,56-960,3$ \\
\hline 5 & Васильківський район & $4(4 / 0)$ & $333-10000,6$ \\
\hline 6 & Білоцерківський район & $5(5 / 0)$ & $79,87-1522$ \\
\hline 7 & Вишгородський район & $1(0 / 1)$ & 13,66 \\
\hline
\end{tabular}

\section{Висновки.}

Зниження якості води спостерігається навесні та восени, коли в систему забору води потрапляють забруднювачі від очистки міських транспортних артерій, а також із промислових викидів. На основі проведених експериментальних досліджень показано, що питна вода з артезіанських джерел 
м. Києва в основному відповідає санітарно-гігієнічним нормам щодо іiі якості, але деякі бюветні системи потребують додаткових заходів для їі очистки.

Вода 3 артезіанських джерел Київської області не відповідає нормам щодо вмісту нітратів, що можна пов'язати із відсутністю систем очистки промислових стічних вод та неконтрольованим застосуванням добрив в сільському господарстві.

\section{Література:}

1. Коваленко О. М. Нітрат- нітритна проблема та шляхи іiі вирішення / О.М. Коваленко, А. І. Горобець, А. М. Кучук // Науч. зап. Харьковского института экологии и социальной защиты. - Х., 2002 - Т. 2. - С. 3-13.

2. МВ 10.2.1-113-2005 Санітарно-мікробіологічний контроль якості питної води. - К. : Міністерство охорони здоров'я України, 2005

3. CAC/RCP 1-1969, Rev. 3-1997 Рекомендований Кодекс міжнародних норм і правил. Основні принципи гігієни харчування.

4. Бювети Києва. Якість артезіанської води./ За ред.. Гончарука В.В.- К.: Геопринт, 2003.- 110 с.

5. Вода питна. Вимоги та методи контролювання якості.: ДСТУ 7525: 2014. К.: Мінекономрозвитку України, 2014. - 29 с.

6. ГОСТ 18826-73. Вода питна. Методи визначення нітратів.

7. ДСТУ ISO 5667-1-2003 Якість води. Відбирання проб. Частина 1. Настанови щодо проекту програм відбирання проб

8. Бордюг Н. С. Оцінка рівня забруднення нітратами питної води децентралізованого водопостачання / Н. С. Бордюг, А. В. Нікіфорова, Л. Ю. Антонюк // Зб. наук. пр. Подільського держ. аграр.-техн. ун-ту. - 2013. - Спец. вип. : Сучасні проблеми збалансованого природокористування : матеріали VIII наук.-практ. конф., 28-29 листопада 2013 р. - С. 101-104.

Науковий керівник: к.т.н., проф. Бессараб О.С Стаття надіслана: 21.03.2017 p.

(C) Бендерська О.В., Коваль М.O

ЦИТ: иа117-043

DOI: 10.21893/2415-7538.2016-05-1-043

УДК 664.681

Чуйко М.М., Назарько В.О. ЯКІСТЬ ПЕЧИВА РІЗНИХ ВІТЧИЗНЯНИХ ТОРГОВЕЛЬНИХ МАРОК ПІД ЧАС ЗБЕРІГАННЯ

Харківський торговельно-економічний інститут Київського національного торговельно-економічного університету,

Харків, О. Яроша 8, 61045

Chuiko M.M., Nazarko V.O.

QUALITY OF COOKIES OF DIFFERENT DOMESTIC BRANDS DURING STORAGE

Kharkiv Trade and Economic Institute of Kiev

National Trade and Economic University,

Kharkiv, O. Yarosh 8, 61045 